\title{
Universiteit
}

Leiden

The Netherlands

\section{On Austrian Regional Economics}

Leen, A.R.; Heijman, W.J.M.

\section{Citation}

Leen, A. R., \& Heijman, W. J. M. (2004). On Austrian Regional Economics. Papers In Regional Science, 83(2), 487-493. Retrieved from https://hdl.handle.net/1887/43292

Version: $\quad$ Not Applicable (or Unknown)

License:

Downloaded from: https://hdl.handle.net/1887/43292

Note: To cite this publication please use the final published version (if applicable). 


\title{
On Austrian regional economics
}

\author{
Wim J.M. Heijman ${ }^{1}$, Auke R. Leen ${ }^{2}$ \\ 1 Department of Social Sciences, Wageningen University, P.O. Box 8130, 6700 EW Wageningen, \\ The Netherlands (e-mail: Wim.Heijman@wur.nl) \\ 2 Tax Law and Economics Department, Leiden University, Faculty of Law, P.O. Box 9521, \\ 2300 RA Leiden, The Netherlands (e-mail: a.r.leen@law.leidenuniv.nl)
}

Received: 2 February 2002 / Accepted: 25 June 2003

\begin{abstract}
The aim of this research note is two-fold, firstly, to clarify the growing interaction between regional science and Austrian economics and their awareness of each other. We elucidate the Austrian methodology, called praxeology, which is especially misunderstood in regional science. Secondly, we tentatively sketch a possible contribution of Austrian economics to regional science. The core of the new economic geography is the idea of external economies of scale. Agglomeration of firms often leads to lower costs of existing products, and is a stimulating environment for the invention of new products and the development of new ideas. Austrian economics, which places discovery at the centre of its analysis of the market process, should be able to explain why (public) regional investments may be unsuccessful and why they can be successful.
\end{abstract}

JEL classification: B41, B53, R12

Key words: Austrian economics, methodology, regional science, regional policy

\section{Introduction}

Nowadays it seems as if regional science is discovering Austrian economics (Hite 1995; Rees 1999) and, one may add, Austrian economics is discovering regional science (Desrochers 1998, 2001). The aim of this research note is to clarify the growing interaction between these two disciplines and their awareness of each other. Sections 2 and 3 focus on methodological misconceptions and on substantive points of misunderstanding. Section 4 considers in what way Austrian economics can contribute to regional science. 


\section{Methodology of the Austrian school}

Two recent articles (Hite 1995; Rees 1999) on the fruitfulness of Austrian economics for regional science show confusion between the substance (the content of Austrian economics) and the method by which the Austrians reach their conclusions. This confusion might originate from the negative opinion of neoclassical economists for Austrian economics, thus inspiring little interest in its achievements. Mark Blaug, a leading historian on the history of economic thought, once said of the method used by the founder of the modern Austrian school of economics: "His (Ludwig von Mises) later writings on the foundation of economic science are so cranky and idiosyncratic that we can only wonder that they have been taken seriously by anyone" (1980, p. 93). To this day, this is still the opinion of a large majority of neoclassical economists.

So what is the Austrian method? It is a method first explicitly written down by Mises $(1949,1966)$ and to a lesser extent, by Friedrich Hayek, the 1974 Nobel prize winner for Economics. Their method is called praxeology (the logic of action), a name that characterises the verbal axiomatic-deductive method of Austrian economics. It is based on a form of introspection shared by everyone, and is characteristic of that used for logical and mathematical truths. Praxeology consists of the verbal elaboration of the logical implications of the fundamental and some subsidiary axioms of human action. Praxeology begins with the fundamental, selfevident axiom that "men act by virtue of their being human". Human beings try to exchange a poor situation for a better one. Things that do not act purposefully are not classified as human beings. A human being that does not act, in other words, who does not behave rationally, changes into a plant; he vegetates. "Human action is necessarily always rational. The term 'rational action' is therefore pleonastic ... The opposite of action is not irrational behavior, but a reactive response to stimuli on the part of the bodily organs and instinct" (Mises 1966, pp. 19-20).

Hence the only test of an economic theory is the truth of the evident premises and the logical analyses built on it. We deduce, save logical errors in the deductive process, true conclusions from a true axiom. So for the Austrians - in so far as the premises are true - economic theory is absolutely true; testing is meaningless. The Austrian methodology stands against the logical positivist one inspired by the natural sciences. The latter method is copied as a role model by modern mainstream neoclassical economics. The Austrians are accused of being unscientific (see Blaug's remark just cited). For the neoclassical, economic laws can only be established tentatively, by testing empirically (verifying or falsifying) the consequences. The praxeologist makes no use of mathematical economics or econometrics. Mathematical formulations are always quantitatively precise, but they are unable to portray qualitative differences. Every step in the market process depends on human decisions that are mental, qualitative and immeasurable. In physics, the preference for its use is based on certain constants. But what if there are only variables (historical data) and no constants? To speak of variables when there are no invariables does not make sense (Rothbard 1951, 1962).

Praxeology has a few broadly empirical axioms, such as that individuals vary in tastes and abilities, that human beings find leisure a valuable good, and that 
people learn from experience. The axiom that people learn from experience is fundamentally important to the description of the market as a systematic sequence of economic states. Its broadly empirical character is based on the general inclination of human beings to be alert to opportunities. Although we recognise that people err, we assume that man tends to notice potential opportunities for gainful action. "The market process emerges as the necessary implication of the circumstances that people act, and that in their action they err, discover their errors, and tend to revise their actions in a direction likely to be less erroneous than before" (Kirzner 1979, p. 30). It is this description of human behaviour and the market process that regional science perceives as the "Austrian" method, which is apparently incorrect. Although regional scientists speak of the Austrian methodology it is in fact the substance they refer to. Regional science, however, should be aware that, for the Austrians, mainstream neoclassical and Austrian methodology are not - as Hite (1995, p. 177) assumes - complementary forms of doing economics.

\section{Substance of Austrian economics}

For modern Austrians the main difference between the neoclassical market model and Austrians' own is that, in theirs, adjustment processes and market disequilibria are central. Adjustment copes with dispersed knowledge and the lack of it. The central point of their approach is the incurable ignorance of most of the particular circumstances that determine the course of society. In contrast to the neoclassics, for the modern Austrians, correct foresight (full knowledge) is not a precondition for the attainment of equilibrium, but the defining characteristic of the state of equilibrium. "The statement that, if people know everything, they are in equilibrium, is true, simply because that is how we define equilibrium" (Hayek 1949, p. 46).

Unlike most cases in the neoclassical model, in the modern Austrian market model, action does not primarily follow from an optimal choice in a given endsmeans relation. At the centre of the modern Austrian market model is the process of conceiving the ends-means relationship. True choice requires the realistic possibility of more than one alternative. Choices are not only concerned with merely selecting the highest out of an array of given and ranked alternatives, but also embrace the perception and evaluation of the alternatives identified as relevant (Kirzner 1989, p. 18).

For the Austrian economist, process, discovery and uncertainty are essential for everyday economics. "It is not that markets work despite the open-ended uncertainty surrounding human action, but rather that they work precisely because of this quality of human action. The open-ended uncertainty of the environment itself provides the scope and possibility for an entrepreneurial process of competitive discovery" (Kirzner 1989, p. 234). The central point of the Austrian approach is man's incurable ignorance. "Thus entrepreneurial activity ... undoubtedly involves uncertainty and the bearing of risk" (Kirzner 1973, p. 78; 1985, pp. 40-67).

Austrians emphasise freedom of contract (making use of decentralised knowledge) as essential for the functioning of markets. Not because it produces perfect efficiency, but because it produces more efficient outcomes than governmental intervention does. According to them, there is no efficient non-market resource allo- 
cation. This was the insight the Austrians tried to bring to the fore in the socialist calculation debate that raged in the 1930s; a debate beginning with the question, "Is an efficient non-market resource allocation possible?" No, says the Austrian. Market-based prices are necessary to signal scarcity, to transmit knowledge and to stimulate discovery. And as Mises concludes: "Inasmuch as money prices of the means of production can be determined only in a social order in which they are privately owned, the proof of the impracticability of socialism necessarily follows. [T] his proof is certainly the most important discovery made by economic theory" (1981, p. 157).

The calculation debate brought to the fore two modern Austrian insights. First, without market-determined monetary prices, rational calculation is impossible in a centralised economy. Subjectivism entails the contention that values cannot be calculated or measured directly. They are calculated with the results of individual valuations: money prices. "For a long time," says Friedrich Hayek, "the misconception that costs determined prices prevented economists from recognising that it was prices that operated as the indispensable signals telling producers what costs it was worth expending on the production of the various commodities and services, and not the other way around" (1978, p. 2). Second, without market-determined monetary prices, a centralised economy lacks ability to promote discovery. "The most impressive aspect of the market system is the tendency for [...] opportunities to be discovered" (Kirzner 1985, p. 30). Prices expressed in money show price discrepancies. Through the possibility of monetary profits, prices stimulate the discovery of valuable concrete information. And it is precisely the institutional setting of the market economy that translates error into prospective net gain. As the Austrians say: The whole organisation of the market mainly serves the need to spread the information on which buyers act. So indeed, the instantaneous global interaction by the Internet can increasingly facilitate market transactions and thereby improve the coordination of plans. However, the sort of knowledge of relevance to Austrian economics is of a completely different order. It is a specific practical kind of knowledge embedded in and dispersed among the minds of millions of people. It is the specific knowledge, of which we do not even know that we have it, or need it, until the moment is there.

The above implies a fundamental difference between the work of Joseph Schumpeter and mainstream modern Austrian economics. Although Schumpeter is widely cited (Rees 1979, 1999; Nijkamp 1987) in the literature on the fruitfulness of Austrian economics for regional science; nowhere in his writings does he use the modern Austrian methodology. And though indeed it is true they both emphasise the entrepreneurial role in the market process, Schumpeter's entrepreneur is, by any standard, no equilibrating force in the market process. In fact, it is quite the opposite; he is a disequilibrating force. Long-run developments in new commodities, technologies, sources of supply and type of organisations are at the core of his idea of market processes. Just about the opposite of the Austrian way of describing the equilibrating competitive-entrepreneurial process of discovery: short-run as well as long-run developmental changes caused by the innovator as well as the imitators who exploit the opportunities exposed by the activities of the innovators. For the Austrian, as opposed to Schumpeter, price competition is as essential to 
entrepreneurship as that represented by the new commodity and new technology (Kirzner 1973, pp. 125-131; 1999, pp. 5-17).

\section{Austrian regional economics}

Austrian economics has a few characteristic features important to regional economics. Firstly, it considers the economy so dynamic that mechanistic modelling does not help us understand it. Secondly, Austrian economics is the science of the process of choice of human actors that is difficult to predict. Actors may react differently to the same stimuli under more or less the same circumstances. Thirdly, economics is considered to be the science of exchange between individual actors, in which government plays no significant role. To put it bluntly, the government is considered to be an agent blocking the process of choice, and should therefore be limited as much as possible. Fourthly, individuals act under uncertainty. Consumers and producers do not have full knowledge of their environment, not in the present and certainly not in the future. This means that there is an element of discovery in the behaviour of economic actors. This includes their attitudes and actions toward risk.

Economic growth is a spatial phenomenon. As Desrochers (1998) puts it: "1. Where prosperity exists, it is regionally based; 2 . The sources of this prosperity are to be found in the regions themselves and not in some exogenous factors". This means that growth is not evenly spread over a country, but is concentrated in centres, which can be called growth poles, clusters, cores, or agglomerations. The reason for this is external economies of scale. Because of these, costs can be reduced and knowledge flows easily between producers, stimulating technological renewals (Desrochers 2001). This element has been present both in regional economics and Austrian economics for a long time, but has been neglected in mainstream general economics. This is the reason why regional and general economics have mainly developed along different lines (Krugman 1995, 1997).

It has been argued that telecommunication technology will diminish the advantages of geographical proximity of especially small, specialist firms. This is probably untrue. High knowledge-intensive activities, like the development of new products need not only face to face contacts, but also "face to product" contacts. By the latter we mean that it is very difficult to replace the physical contact between buyer and product by means of telecommunication of abstract descriptions. It is also difficult to provide after sale service in that way. Only standardised operations and products may become footloose, because of new ways of telecommunication (Desrochers 1998).

The uneven regional distribution of economic development is the basis for regional policy. Mainstream regional economics is mechanistic by nature. For Krugman $(1995,1997)$, even regional economics is a science of modelling. In essence, this means that economic subjects, just like rats, react to economic stimuli always in the same way (Hite 1995). This has an element of truth in it in the short-run. In the long-run, however, technological renewal and creative destruction change the way of life, and with that, the behaviour of choice of consumers and producers. The mechanistic nature of regional economics and regional policy based on it is also the 
reason for failures in the attempts of stimulating backward regions by public investments. In this respect the Austrian approach resembles the behaviouristic "prospect theory" in its criticism on the rigid assumptions of neoclassical economics, in which a concept like "loss aversion" is considered a non-rational aberration of human behaviour (Tversky and Kahneman 2000). ${ }^{1}$

The mechanistic view of clusters or growth poles is that it is quite simple to stimulate economic growth in a region that lags behind.;onstructing a growth pole will cause regional economic growth to come automatically.

In several European countries in the past (1960s and 1970s), even a growth pole policy existed, which intended to stimulate backward regions by the public initiation of growth poles or clusters. Generally speaking, it was not successful. Austrian economic theory aims at explaining why regional investments may be unsuccessful and how they can be successful.

Austrian economic theory would argue that the market is the key factor in regional development, and that although it is possible for the government to stimulate existing promising regional economic activities, it is not possible to generate a growth pole out of nothing. Because so many specific regional circumstances must be taken into account, central government simply lacks the information to be successful in this. Further, clustering of economic activities and, as a consequence, unevenly distributed regional development, are inevitable elements of national economic growth. This theory would conclude that evenly distributed regional economic growth is a contradiction, and that therefore regional economic policies aiming at that are doomed to fail. The spatial clustering of economic activities is a market phenomenon to be fostered by the public administration, but it cannot be initiated by it.

\section{References}

Blaug M (1980) The methodology of economics. Cambridge, Cambridge and London

Desrochers P (1998) A geographical perspective on Austrian economics. The Quarterly Journal of Austrian Economics 1(2): 63-83

Desrochers P (2001) Geographical proximity and the transmission of tacit knowledge. The Review of Austrian Economics 14(1): 25-46

Hayek FA (1949) Individualism and economic order. Routledge \& Kegan Paul, London

Hayek FA (1978) Coping with ignorance. Imprimis 7: 1-5

Hite J (1995) We are not rats: Seeking a regional version of Austrian economics. International Regional Science Review 17: 249-296

Kirzner IM (1973) Competition and entrepreneurship. University of Chicago Press, Chicago

Kirzner IM (1979) Perception, opportunity and profit. Studies in the theory of entrepreneurship. University of Chicago Press, Chicago

Kirzner IM (1985) Discovery and the capitalist process. University of Chicago Press, Chicago

Kirzner IM (1989) Discovery, capitalism and distributive justice. Basil Blackwell, Oxford and New York

Kirzner IM (1999) Creativity and/or alertness: A reconsideration of the Schumpeterian entrepreneur. Review of Austrian Economics 11: 5-17

1 Loss aversion implies that losses and disadvantages have greater impact on preferences than gains and advantages (Tversky and Kahneman 2000, p. 143). This might have implications for the location of firms and regional development (Smith 1971, 1981). 
Krugman P $(1995,1997)$ Development, geography and economic theory. The MIT Press, Cambridge, MA

Mises L von $(1949,1966)$ Human action: A treatise on economics. Contemporary books, Chicago

Mises L von (1981) Epistemological problems of economics. Princeton, New York

Nijkamp P (1987) Long-term economic fluctuations: A spatial view. Socio-Economic Planning Sciences 21: $189-197$

Rees J (1979) Technological change and regional shifts in American manufacturing. Professional Geographer 31: 45-54

Rees J (1999) Regional science: From crisis to opportunity. Papers in Regional Science 78: 101-110

Rothbard MN (1951) Praxeology: Reply to Mr. Schuller. American Economic Review (December) 943 946

Rothbard MN (1962) Man, economy and state. Van Nostrand, Princeton, NJ

Smith DM (1971, 1981) Industrial location: An economic geographical analysis. John Wiley, New York

Tversky A, Kahneman D (2000) Loss aversion in riskless choice: A reference-dependent model. In: Kahneman D, Tversky A (eds) (2000) Choices, values and frames. Cambridge University Press, Cambridge (UK) 